\title{
Venäjän pohjoisia kirjallisuuksia tutkimassa
}

Venäjän arktinen alue on 2000-luvulla noussut ympäristötieteellisen ja enenevässä määrin myös humanistisen tutkimuksen kohteeksi. Pohjoisiin seutuihin Euroopan-puoleisilta alueilta Siperiaan saakka kohdistuneet ekologisesti kestämättömät toimet ovat herättäneet huolta herkän luonnon peruuttamattomasta tuhoutumisesta ja alueen alkuperäiskansojen tilanteesta.

Suomalaisessa kulttuurintutkimuksessa arktisia alueita on perinteisesti tarkasteltu uralilaisten kansojen kieli- ja kansatieteellisen tutkimuksen piirissä, mutta viime aikoina myös Venäjän-tutkijat ovat kiinnostuneet arktisen alueen tarjoamista tutkimusaineistoista ja uudenlaisista lähestymistavoista. Kirjallisuudentutkimuksessa tämä on tarkoittanut niin modernisaation diskurssien erittelyä pohjoista käsittelevässä venäläisessä kirjallisuudessa ja kulttuurissa kuin pohjoisten alueiden omiin kirjallisuuksiin kohdistuvaa tutkimusta. Pohjoinen kirjallisuus yhdistyy ensinnäkin Venäjän luoteisosan kautta hahmottuvaan Pohjolaan (Russki Sever), toisekseen pohjoiseen kirjallisuudessa liitettävään mielikuvastoon ja kolmanneksi niin sanottuihin pohjoisiin alkuperäiskansoihin, jotka asuttavat laajoja alueita niin Venäjän pohjoisessa kuin Siperian etelä- ja pohjoisalueillakin.

Globaalissa mittakaavassa arktisen alueen kulttuurintutkimuksessa on noussut keskeiseksi arktisismin (Arcticism) käsite, joka juontuu Edward Saidin orientalismin käsitteestä ja siten viittaa jälkikolonialistisen ajattelun värittämään ymmärrykseen länsimaisen modernisaation suhteesta pohjoisiin seutuihin. Arktisismin puitteissa on oikeutettu pohjoisten alueiden haltuunotto toistamalla mielikuvia samanaikaisesti niin asuttamattomasta seudusta kuin toisaalta jälkeenjääneestä, historiattomasta ja perinteisestä elämäntavasta, jonka säilyminen edellyttää nykyaikaistamista. 
Venäjän kohdalla arktiset kysymykset ovat jo varhain kiinnittyneet valtion talouteen, geopoliittisiin intresseihin ja teknologiseen modernisaatioon. Vuosisatojen ajan kestänyttä laajentumista pohjoiseen ja itään on ympäröinyt imperialistinen diskurssi. Pohjoisen luonnonvaroilla oli suuri rooli jo Novgorodin tasavallassa, jonka rikkaus perustui turkiskauppaan. Venäjän keisarikunnassa kiinnostuttiin arktisista alueista 1700-luvulla, kun pohjoiseen ja sen luonnonvaroihin alettiin kiinnittää huomiota Venäjän taloudellisen kasvun ja Euroopan kanssa käytävän valtakilpailun mahdollistajana. 1800-luvun loppupuolella kehitys kiihtyi: siinä missä varhaisempaa 1800-lukua värittivät Siperian kansoista ja kulttuureista kiinnostuneiden tutkimusmatkailijoiden retket, 1900-luvun taitetta lähestyttäessä matkaan lähtivät myös hallinnon edustajat kuten talousministeri Sergei Witte vuonna 1894. Nuoressa neuvostovaltiossa 1920- ja 1930-luvuilla taloudellinen ja geopoliittinen kiinnostus pohjoiseen kehittyi systemaattiseksi arktisten alueiden kartoittamiseksi ja kolonisaatioksi, jota tavataan kutsua pohjoisen valloittamiseksi tai omimiseksi (osvojenije Severa) ja joka jatkuu eri muodoissa edelleen.

Venäjän arktisiin alueisiin jo varhain kohdistuneen kolonisaation ja Neuvostoliiton aikana kiihtyneen modernisaatiokehityksen monimutkaiset seuraukset ovat nähtävissä paitsi pohjoisessa luonnossa ja pohjoisissa yhteisöissä myös kirjallisuudessa. Venäläisessä kirjallisuudessa toisintuu kolonisaatiodiskurssille ominainen keskuksen ja periferian välinen asetelma, jossa pohjoinen esitetään usein joko romantisoituna venäläisen kulttuurin kehtona tai tieteen ja teknologian avulla valloitettavana toistaiseksi sivistymättömänä alueena. Sekä pohjoista romantisoivan kirjallisuuden että varsinkin sosialistisen realismin hengessä kirjoitetut valloituskertomukset voi nähdä arktisismin muotoina, joissa pohjoiset merkitykset määritetään venäläisen kulttuurin näkökulmasta.

Valloittamisen diskurssin rinnalla kaunokirjallisuudessa esiintyy kuitenkin myös toisenlaisia pohjoisten seutujen hahmottamisen tapoja. Varsinkin 1960-80-lukujen maaseutukirjallisuudessa (derevenskaja proza) nostetaan esiin luonnonvarojen hyötykäyttöön liittyviä eettisiä ja moraalisia ongelmia, jotka osin yhdistetään juuri Venäjän pohjoiseen. Alkuperäiskansoille kuten nenetseille, kuolansaamelaisille tai tšuktšeille taas kirjallisuus on itsessään ollut moderniuden esittämisen keino. Pohjoinen näyttäytyykin alkuperäiskansojen kirjallisuudessa sekä kotiseutuna että modernisaation trooppien kuten valon, sähkön, teollisuuden ja sosialismin vastaanottajana. Kuitenkin myös pohjoisten alkuperäiskansojen kirjallisuudessa alkoi esiintyä modernisaatiokritiikkiä 1960-ja 70-luvuilla. Jälkineuvostoliittolaisessa kirjallisuudessa puolestaan arktisen alueen historiaa kuvataan usein kaupungistumisen kautta. Arktisen urbaanin tilan ja luonnonympäristöjen suhde nostaa myös kaunokirjallisuudessa esiin kysymyksiä pohjoisen kolonisaatiosta sekä nykysukupolven suhteesta neuvostomenneisyyteen.

Venäjän alkuperäiskansojen kirjallisuuteen kohdistuva tutkimus ja venäläisen kirjallisuuden tutkimus ovat perinteisesti olleet melko eriytyneitä alueita. Kiinnostus Venäjän pohjoisten vähemmistöjen oma- tai venäjänkieliseen kirjallisuuteen on ollut marginaalista ja keskittynyt tyypillisesti pohjoisten alueiden omiin tutkimuslaitoksiin. Arktisen alueen kirjallisuus on kuitenkin luonteeltaan ylirajaista, pitkien kulttuurikontaktien myötä erityisesti venäläisen kirjallisuuden ja kulttuurin kanssa läheisessä suhteessa kehittynyttä kirjallisuutta. Luonteeltaan pohjoinen kirjallisuus on alueellista ja paikallisiin oloihin, sen yhteisöihin ja näiden vuorovaikutukseen keskittyvää.

Kirjallisuudentutkimuksen kannalta yksi kiinnostavimmista kysymyksistä onkin pohjoisten kirjallisuuksien suhde vallitseviin ideologioihin ja kirjallisiin traditioihin. Niinpä sen keskeisten ulottuvuuksien kuten luonnon ja ihmisen suhteen käsittämisen ja esittämisen 
tapojen sekä näissä tapahtuvien muutosten tarkasteleminen venäläisen ja neuvostoliittolaisen kirjallisuuden kontekstissa tuntuu hedelmälliseltä ja tuoreelta maaperältä.

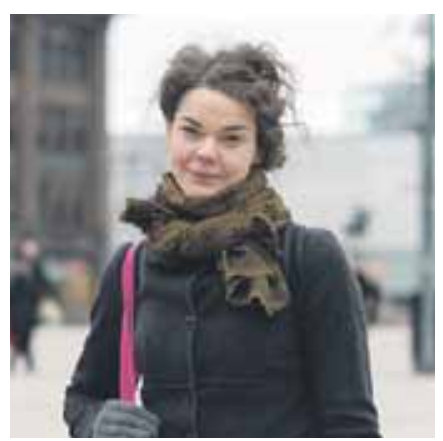

\section{Tintti Klapuri}

Kirjoittaja on venäläisen kirjallisuuden yliopistonlehtori Helsingin yliopistossa ja johtaa tutkimushanketta "Pohjoiset naapurit: Luonto ja ihminen Venäjän arktisen alueen kirjallisuuksissa" (Koneen Säätiö, 2019-22).

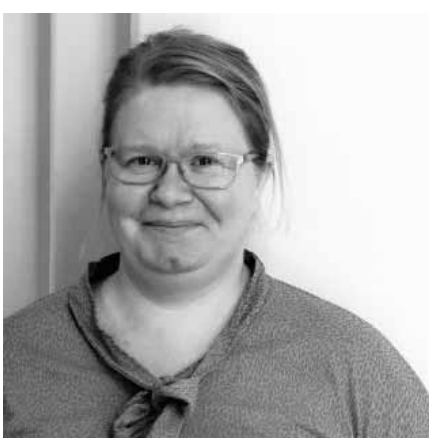

\section{Karina Lukin}

Kirjoittaja on akatemiatutkija (hanke "Imperialismi kansanomaisin silmin: Folkloren, perinteen ja kulttuuriperinnön kolonialistisuus nenetsien tutkimushistoriassa ja nykypäivässä"; SA330374) Helsingin yliopiston folkloristiikan oppiaineessa ja toimii myös Pohjoiset naapurit -hankkeessa. 


\section{Lukunautintoja Innolta -}

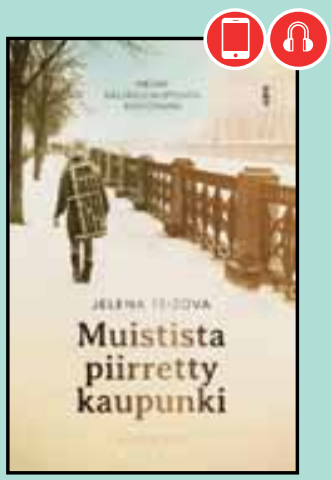

Jelena Tšižova

MUISTISTA

PIIRRETTY

KAUPUNKI

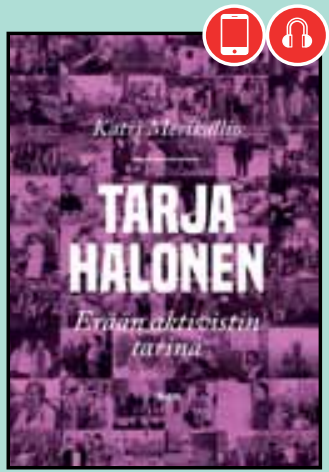

Katri Merikallio

TARJA HALONEN

ERÄÄN AKTIVISTIN

TARINA

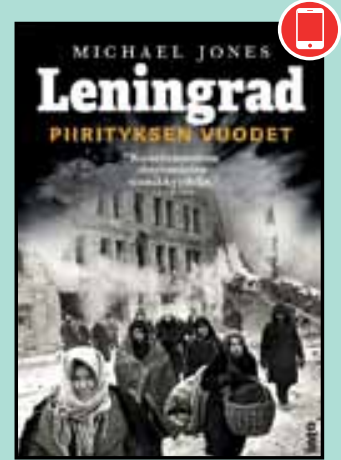

Michael Jones

LENINGRAD

PIIRITYKSEN VUODET

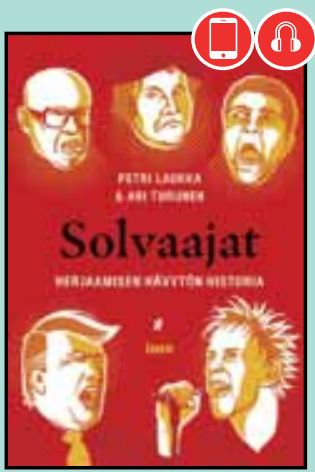

Petri Laukka

\& Ari Turunen

SOLVAAJAT

HERJAAMISEN

HÄVYTÖN HISTORIA

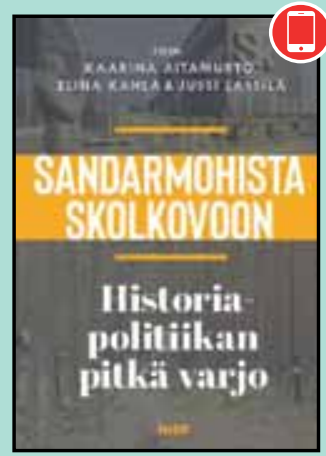

Kaarina Aitamurto, Elina Kahla

\& Jussi Lassila (toim.)

SANDARMOHISTA SKOLKOVOON HISTORIAPOLITIIKAN PITKÄ VARJO

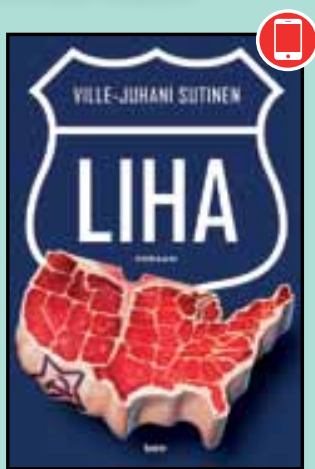

Ville-Juhani Sutinen LIHA
(1) = Myös e-kirjana
$(B)=$ Myös äänikirjana

Kirjakaupoista ja osoitteesta: intokustannus.fi into 